\title{
Licensing Foreign Technology and the Moderating Role of Local R\&D Collaboration: Extending the Relational View
}

\author{
Wang, Yuandi; Li-Ying, Jason
}

Published in:

Journal of Product Innovation Management

Link to article, DOI:

10.1111/jpim.12246

Publication date:

2015

Document Version

Peer reviewed version

Link back to DTU Orbit

Citation (APA):

Wang, Y., \& Li-Ying, J. (2015). Licensing Foreign Technology and the Moderating Role of Local R\&D

Collaboration: Extending the Relational View. Journal of Product Innovation Management, 32(6), 997-1013. https://doi.org/10.1111/jpim.12246

\section{General rights}

Copyright and moral rights for the publications made accessible in the public portal are retained by the authors and/or other copyright owners and it is a condition of accessing publications that users recognise and abide by the legal requirements associated with these rights.

- Users may download and print one copy of any publication from the public portal for the purpose of private study or research.

- You may not further distribute the material or use it for any profit-making activity or commercial gain

- You may freely distribute the URL identifying the publication in the public portal 


\title{
Please cite this article as:
}

Wang, Y. and Li-Ying, J. (2015). Licensing foreign technology and the moderating role of local R\&D collaboration: Extending the relational view. Journal of Product Innovation Management, 32(6): 9971013.

\section{Licensing foreign technology and the moderating role of local R\&D collaboration: Extending the relational view}

\author{
Yuandi Wang \\ Sichuan University \\ Business School of Sichuan University \\ No. 29, Wangjiang Road \\ Chengdu, 610064, Sichuan, China \\ Email: wangyuandi@scu.edu.cn \\ Jason Li-Ying * \\ Technical University of Denmark \\ DTU Management Engineering \\ DK-2800 Kgs. Lyngby, Denmark \\ Tel: +4545256121 \\ Email: yinli@dtu.dk \\ *Corresponding author
}

\begin{abstract}
Authors' Bio
Yuandi Wang, $\mathrm{PhD}$, is an associate professor at the Business School of Sichuan University, China. $\mathrm{He}$ received his $\mathrm{PhD}$ from Hasselt University in Belgium. He has been researching in the fields of technology transfer, innovation internationalization, and national innovation systems. His work has been published in journals such as Technological Forecasting and Social Change, International Journal of Innovation and Regional development, International Journal of Technology Management, Journal of Technology Transfer, Scientometrics, IEEE Transactions on Engineering Management, Technovation, European Management Journal, and International Business Review.
\end{abstract}

Jason Li-Ying, $\mathrm{PhD}$, is an associate professor at Technical University of Denmark, department of DTU Management Engineering. His research interests include open innovation, technology transfer, and technological capability building by firms in developing countries. His work has been published in journals such as Creativity and Innovation Management, International Journal of Innovation Management, R\&D Management, Technovation, Journal of Technology Transfer, Scientometrics, Multinational Business Review, and Long Range Planning. 


\begin{abstract}
The relational resource-based view posits that performance differences among firms can be explained not only by the possession of internal resources but also by maintaining and developing relationships with external partners. However, studies in the extant literature usually address the separated roles of various external relationships of focal firms, but the literature has not addressed how relationships with different sets of knowledge partners are related to each other and influence focal firms' performance. Therefore, to fill this research gap, this study focuses on how technological resources acquired from one set of partners (licensing foreign technologies) may generate subsequent internal and relational rents in terms of technological innovation in the context of collaboration with an entirely different set of knowledge partners (local $R \& D$ partners). Specifically, we propose that local $R \& D$ collaborations need to be large in scale and broad in scope. The empirics are based on the analysis of a sample of 160 high-tech Chinese firms observed from 2000 to 2011. Consistent with our predictions, our findings contribute to extending the relational view by addressing the relations among the relationships of focal firms.
\end{abstract}

Key words: R\&D collaboration; technology licensing; university; innovation; relational resource-based view; China

\title{
Acknowledgement
}

This work is supported by the National Science Foundation of China [grant no.71302133], Youth Project of Ministry of Education, Humanities and Social Sciences Planning Funding [grant no. 13YJC790154], and the funding of Sichuan University [grant no.skyb201302]. We also recognize the support from the social science (innovation management theme) research funding of the Sino-Danish Centre 2013-2014, Denmark. 


\section{Introduction}

The interconnection between a firm's internal and external resources and its collaborative relationships challenges the traditional resource-based view (RBV) (Barney, 1991) and requires a relational view (Dyer and Singh, 1998). As different types of external linkages provide different sets of resources and relationships with partners (Chiaroni et al., 2010; Lin, 2003; Tsai and Wang, 2007), the relational view posits that a firm's performance is mainly the consequence of developing and appropriating internal rent and relational rent, resulting from the focal firm's non-shared resources and resources shared with collaboration partners, respectively (Lavie, 2006).

However, the limitations of the literature on the relational view to date are twofold. First, some prior studies address groups of homogenous collaboration partners that provide similar types of external resources and share similar relational characteristics (e.g., Sherwood and Covin, 2008; van Beers et al., 2008; van Burg et al., 2013). For instance, studies on supplier-buyer relationships discuss how suppliers provide knowledge inputs for the buyers' innovation ( $\mathrm{Li}$ and Vanhaverbeke, 2009). Studies on strategic alliances focus on the relationships among the features of alliance partnerships and the partners' resource contributions (e.g., Lavie and Rosenkopf, 2006; Vanhaverbeke et al., 2002; van der Vrande et al., 2006; Jiang et al., 2010). Second, even though some prior studies address the roles of multiple types of collaboration partners, "relationships" merely refers to relationships between a focal firm and its partners, and the discussion about resources and relationships has been bounded within a particular set of partners of the focal firm (e.g., Knudsen, 2007; Un et al., 2010; van Beers and Zand, 2014). Therefore, the extant literature has not sufficiently informed us about how a focal firm's relationships with partners are related to each other and how variance across the relationships with different types of partners could possibly affect the 
generation of relational rents that are tied to some partners' resources. This results in a research gap that prevents the relational view as a theory from being truly "relational."

This article focuses on a specific case where firms in a particular country license technology from foreign partners because similar technological resources are unavailable in the domestic market and collaborations with local partners become a crucial means to recognize and exploit new opportunities that lie in the in-licensed foreign technology (Wang and Zhou, 2013; Foss et al., 2013). To our knowledge, little is known about how technological resources acquired from one set of partners (foreign licensors) may generate subsequent internal and relational rents in terms of technological innovation in the context of collaborations with an entirely different set of knowledge partners (local R\&D partners).

This article focuses on the enabling functions of a firm's local R\&D partners that help licensee firms effectively acquire and absorb foreign technological resources and enhance their technological innovation performance ${ }^{1}$. More precisely, this article investigates whether a firm's local R\&D collaborations on a large scale (how many) and with a broad scope (how many types) help a focal firm generate relational rents tied to in-licensed foreign technologies, as both the scale and the scope of collaborations affect the generation of potential relational rents, according to the relational view (Lavie, 2006). The empirical base of this study is a sample of 160 Chinese firms in the high-tech sector. Data on these firms' technology licensing from foreign sources and their co-patenting with local partners from 2000 to 2011 are used to answer the research questions.

This study makes a theoretical contribution to the literature on strategic management of innovation, as it advances the relational view by specifically investigating how resources gained from one set of collaboration (licensing foreign technology) enable a firm to generate rents under the condition of scale and scope differences in other collaborations (local R\&D collaborations). In this way, this article is able to extend the relational view to a new stage, 
accounting for the "relations among relationships." This also has practical implications, suggesting that managers should pay attention not only to managing the relationships with partners but also to achieving the synergic exploitation of external resources from different partners.

The remainder of this article is organized as follows. First, it starts with a literature review of the relational view, technology licensing, and $R \& D$ collaboration with regard to their roles in a firm's technological innovation performance. Next, the conceptual model and develop the hypotheses are proposed. After that, the data and methods used in this study are described. Next, the empirical results are presented in detail. Finally, this article concludes with discussions about the findings, addressing some limitations, and suggesting directions for future study.

\section{Conceptual background}

\section{Licensing foreign technologies and local R\&D collaboration}

According to the RBV, technological resources from foreign origins are crucial for innovation because they provide firms with strategic assets that are domestically unavailable (Nelson and Winter, 1982; Schumpeter, 1934) and compensate for the technical competence that they lack (Kogut and Zander, 1992). With sophisticated international capital and technology markets, firms are now able to engage directly in international technology licensing. However, technology developed in one country is usually related to a country's factor endowments (i.e., natural resources, labor, capital, and entrepreneurship), market structure, and customer preference (Acemoglu, 2002). Thus, it might not be directly applicable in another country with a set of significantly different factors. With in-licensed foreign technology, a firm needs sufficient absorptive capacity to learn and ensure the effective exploitation of new opportunities (Cohen and Levinthal, 1990; Li and Kozhikode, 2009). However, as a firm's absorptive capacity may not be strong in all respects and developing absorptive capacity 
internally is not necessarily the only or the best strategy (van Dijk and Bell, 2007), firms are largely motivated to collaborate with local $R \& D$ partners as critical knowledge complements to adapt new technology to their specific domestic context (Liefner et al., 2006).

Local R\&D collaboration can provide valuable supplementary technological knowledge for firms and further enhance their technological innovation performance (Dodgson, 1992). Multiple local organizations are available for R\&D collaboration. The extant literature has recognized at least the following three major types of local $R \& D$ collaboration partners: universities, research institutes, and industrial firms (Belderbos et al., 2004; van Beers et al., 2008). The typical role of universities as major knowledge suppliers has been identified and analyzed by addressing the characteristics of the firm (as a knowledge recipient) and universities (as knowledge creators), the geography of localized spillovers, and the different channels of knowledge transfer (see the early review on university-industry collaboration by Agrawal, 2001). Since the Bayh-Dole Act of 1980 in the United States granted universities the right to apply for patents on the basis of federal funding and to license out these patents, there has been an increase in university participation in the patenting domain (Henderson et al., 1998; Mowery and Shane, 2002). Recent evidence in the United States and the E.U. has shown that universities' direct contribution to commercially viable technology is much patchier than expected (Yusuf, 2008) and suggested that universities function as catalysts rather than representing a major direct source in university-industry collaboration (Hershberg et al., 2007; Ahrweiler et al., 2011). The catalyst role has been played through various mechanisms, such as spin-offs, mobile employees, contract research, and informal knowledge exchange to transfer tacit knowledge (Wright et al., 2008; Kodama, 2008; Fontana et al., 2006; Lehrer et al., 2009; Ponds et al., 2010). The second type of local $\mathrm{R} \& \mathrm{D}$ collaboration partner is research institutes. In most Western countries, the roles of universities and research institutes are similar, as all public research institutions share similar 
resources and organizational settings (van Beers et al., 2008; Miotti and Sachwald, 2003). The third type of local R\&D collaboration partner is industrial firms, which may be competitors, customers, suppliers, or strategic alliances (Belderbos et al., 2004; Un et al., 2010). Thus, collaboration with universities and research institutes is often different from collaboration with industrial firms in terms of topics, application potential, and the scale of budget (Belderbos et al., 2004).

The extant literature has widely accepted that local $R \& D$ collaboration is a critical source of external resources and that relationships with local partners must be managed carefully (Vanhaverbeke et al., 2002; van der Vrande et al., 2006; Jiang et al., 2010). However, local R\&D collaborations neither guarantee that all critical technological resources will be available within a single country nor suggest that critical technological resources must be developed within the same country. In fact, firms often rely on licensing technology from foreign sources. This is particularly the case for latecomer firms in developing countries. Instead of functioning as two parallel sources of external knowledge, licensing technology from foreign countries and collaboration with local R\&D partners may contribute to a firm's innovation by creating synergy. Therefore, there is a need to understand conceptually the relations between the two sets of external knowledge sources of the focal firms, i.e., licensing foreign technology and local R\&D collaboration.

\section{Conceptual framework from the relational view}

The theoretical departure for our conceptual framework is the relational view (Lavie, 2006). As the importance of external knowledge sources that reside in the network of partners has been gradually recognized (Foss et al., 2013), the relational view has argued that critical resources may span firm boundaries and that full ownership and control of these external resources is not only unnecessary but also undesirable (Gulati, 1999; Dyer and Singh, 1998). 
In his seminal work, Lavie (2006) reformulated the RBV for an interconnected firm by suggesting that a firm's competitive advantage comes from three main sources: first, the focal firm's internal resources generate "internal rent"; second, "appropriated relational rent" results from deliberately recombining, exchanging, and co-developing idiosyncratic shared resources between the focal firm and its partners; and third, a firm may also receive unintended benefits owing to both shared and non-shared resources of partners due to an “inbound spillover" effect ${ }^{2}$.

Our conceptual framework, adapted from Lavie (2006) for this specific context, is illustrated in Figure 1. First, technology licensed from foreign origins is a resource that can be either non-shared or shared with local R\&D partners later. Non-shared resources, combined with other internal resources (e.g., trade secrets and internally developed technologies), generate internal rent; shared resources, combined with other shared resources within the firm and from R\&D partners (e.g., brand equity, exchange of R\&D personnel, and cross-licensed technologies), generate appropriated relational rent. Moreover, even non-shared in-licensed foreign technology may benefit from local $R \& D$ collaboration because partners' resources, regardless of being shared or non-shared with the focal firm, indirectly help the focal firm to verify the value of the in-licensed technology or to identify relevant complementary technologies. This is how inbound spillover rent can be created. In this way, the dual role of local $R \& D$ collaboration in relation to in-licensed foreign technology may be viewed as: on the one hand, for the non-shared technological resources, local R\&D collaboration functions as a "screener"; on the other hand, for the shared technological resources, local R\&D partners become "co-developers."

Insert Figure 1 here 
The extant literature on the relational view in general agrees that a firm's technological innovation performance is associated with (1) the scale of collaboration with external partners, as a large resource set of partners provides the firm with a great number of knowledge elements that increase the idiosyncratic nature of its knowledge base, which in turn allows firms to benefit from many opportunities of novel combinations (Fleming, 2001; Li, 2010; Katila and Ahuja, 2002; Laursen and Salter, 2006), and (2) the scope of collaborating partners due to their complementary information and synergistic effects resulting from organizational learning (van Beers and Zand, 2014). A recent study even finds that the relationship between technology licensing and a firm's technological capabilities is positively moderated by the scale of local collaborations (Wang and Zhou, 2013). However, the extant literature does not address whether both the scale and scope of one set of collaboration partnerships matter for the focal firm to generate rent based on another source of external resources. In the next subsection, hypotheses are developed to address this unanswered question.

\section{Hypotheses}

\section{Technology licensing and technological innovation performance}

According to the RBV, firms are motivated to in-source foreign technologies because they reasonably expect a high return on investment from direct access to (and immediate application of) these technologies. Technology licensing usually involves more than just a licensing contract. Rather, licensing contracts are usually accompanied by related technology assistance, training, and support. In this way, firms benefit from international technology inlicensing because they can gain knowledge from the interactive and multifaceted learning process associated with the transfer of foreign technology (Chen and Sun, 2000). Thus, a positive "learning-by-doing" effect is expected. Moreover, technology licensing from foreign sources in advanced countries can stimulate a firm's internal R\&D because technology recipients are usually urged to upgrade their $R \& D$ investments to utilize effectively and 
further develop the in-sourced technology (Katrak, 1990). This, in turn, strengthens a licensee firm's technological capabilities and potentially enhances its technological innovation performance, which can be measured by, for instance, a licensee firm's new patent applications or products (Stuart and Podolny, 1996). Indeed, many researchers have stressed that technology licensing from foreign origins offers firms-particularly those in developing countries-a unique and valuable opportunity to access state-of-the-art technology and learn about the latest technological developments (Chatterji and Manuel, 1993; Leone and Reichstein, 2012; Li-Ying and Wang, 2014). In this context, we predict our baseline hypothesis as follows:

Hypothesis 1: Technology licensing from foreign origins is positively associated with the licensee firm's subsequent technological innovation performance.

\section{Moderating effects of collaboration with local R\&D partners}

To build on in-licensed foreign technologies and innovate further, firms may seek various types of local knowledge partners within a national innovation system (Gulati and Singh, 1998). Following the literature on the relational view, this article focuses on the scale (how many partners) and scope (how many types of partners) of local R\&D collaborations. We expect that a large scale and a broad scope of collaboration with local R\&D partners may pay off ( $\mathrm{Li}$ and Kozhikode, 2009), as they create sufficient complementary technologies (Deolalikar and Evenson, 1989; Kumar, 1987; Liefner et al., 2006; Madanmohan et al., 2004; Zhou, 2012) and form powerful inter-organizational governance through network effects (Nooteboom, 2004).

In line with the extant literature, we argue that, when the scale of collaborations with local R\&D partners is at a high level, the licensee firm is highly likely to benefit from the licensed foreign technology for a number of reasons. First, successful technology diffusion requires an environment that facilitates interaction and communication between technology 
suppliers and recipients (Dyer and Singh, 1998). Thus, cross-border technology licensing is vulnerable to communication barriers due to different languages, cultures, and institutions (Lin, 2003). The challenges associated with licensing foreign technology require assistance from local partners. Second, collaboration with local R\&D partners becomes particularly important for the licensee firm when a licensed technology is new to the country and its future potential for further innovation is initially unclear because local $R \& D$ collaborations can help firms strengthen their absorptive capacity by compensating for their insufficient technological knowledge and limited experience of external learning (Li and Kozhikode, 2008). Third, there are risks in technology transfer and costs of innovation (Williamson, 1975). For a licensee firm, identifying relevant technology, verifying the value of technology, and developing new technology based on in-licensed technology can sometimes prove to be a challenge (Nooteboom, 2004). It is even more risky and costly if technology is to be transferred between nations, as it usually suffers from double-sided moral hazard problems (Arora, 1996; Arrow, 1962), meaning that a technology supplier may not send its best engineers to the recipient firm and therefore provide insufficient technical service, or some important trade secrets may not be revealed to technology recipients (Desai, 1988; Scott-Kemmis and Bell, 1985). Thus, costs are incurred during the initiation, negotiation, monitoring, adaptation, and evaluation of a technology transfer (Palay, 1984). A firm's internal assets and competences are not always sufficient to cope with these challenges. A large scale of collaborations with local R\&D partners may help in monitoring these risks and reducing costs for local firms through their exposure to a large pool of partner-generated knowledge and a network of knowledge institutes (Zhou, 2012). This argument is in line with the social network view, which recognizes that a firm with a large degree of outreach may take advantage of its centralized position in its network (Burt, 1992). 
Based on the relational view as illustrated in Figure 1, we suggest that, with largescale local R\&D collaboration, a licensee firm may have a higher propensity to generate (1) appropriated relational rent, as a large number of shared resources from partners may help the focal firm to understand the licensed technology through co-development, and (2) inbound spillover rent as a large pool of non-shared resources from many local partners performs a screening role. Therefore, the following is hypothesized:

Hypothesis 2: The scale of local $R \& D$ collaborations with universities, research institutes, and industrial firms positively moderates the relationship between the licensing of foreign technology and the licensee firm's subsequent technological innovation performance.

Likewise, we argue that, when the scope of collaboration with local R\&D partners is at a high level, the licensee firm may have a high possibility of benefiting from the foreign licensed technology for a number of reasons. First, previous studies have suggested that innovations often result from a recombination of existing components of knowledge into new syntheses (Fleming, 2001; Kogut and Zander, 1992). Adopting foreign technologies can thus be regarded as a process in which a licensee firm absorbs and integrates parts of the licensed technology into its own knowledge base. Integrating these two hitherto separate knowledge bases may augment the recipient's potential to generate inventive recombination for innovations (Ahuja and Katila, 2001). Here, a diversified group of local collaborators is more likely to provide knowledge sources complementary to the foreign technology (Liefner et al., 2006; Zhou, 2012; Li-Ying et al., 2014). Complementary assets provided by local R\&D partners serve as a third knowledge base to maximize the combinative potential of different knowledge bases (Gulati and Singh, 1998). Second, a broad scope of local R\&D collaboration helps firms to verify the value of technological input from one particular partner by consulting another and identify relevant complementary technology within the local network through an effective triangulation mechanism (Podolny, 2001). Thus, only those firms that keep their 
options open by collaborating with various types of partners may potentially learn from the licensed foreign technology and further innovate (Van de Vrande et al., 2006).

Based on the relational view as illustrated in Figure 1, we suggest that, with a broad scope of local R\&D collaboration, a licensee firm may have a higher propensity to generate (1) appropriated relational rent, as diversified shared resources from partners may help in understanding the licensed technology through co-development, and (2) inbound spillover rent, as a diversified pool of non-shared resources of local partners performs the screening role more effectively. Therefore, the following is hypothesized:

Hypothesis 3: The scope of local $R \& D$ collaboration with universities, research institutes, and industrial firms positively moderates the relationship between the licensing of foreign technology and the licensee firm's subsequent technological innovation performance.

To summarize, we argue that licensing foreign technology is a crucial external technological resource for a firm's technological innovation performance. The contribution of technology licensing can be facilitated by R\&D collaboration with local universities, research institutes, and industrial firms in different scales and scopes. In the next section, the empirics upon which the hypotheses are tested will be described.

\section{Methods}

\section{Data and sample}

The dataset used for this study was obtained from the State Intellectual Property Office of China (SIPO). According to Chinese legislation ('Regulations on Administration of Record Filing of Technology Licensing'), since 2001 SIPO has been authorized to register technology-licensing contracts within three months after a contract is signed between the licensor and licensee. Each technology transfer record registered at SIPO contains the following information: licensor's name, licensee's name, licensing patent number, patent title, 
contracting number and date, and license type (exclusive or non-exclusive). License agreements can be signed between individuals and firms in various forms. While licensors of a licensing agreement can be either Chinese or foreign individuals or firms, all licensees are Chinese individuals or firms. So far, this dataset only includes licensing agreements that involved patented technologies. The complete records from 2000 to 2010 are available to the public on the SIPO website (http://www.sipo.gov.cn/) at the time when this research was done. During these 11 years there were a total of 17,835 license agreements covering 40,623 transferred patents. A total of 7,758 licensors (including 3,917 individuals) and 7,046 licensees (including 62 individuals) entered into license agreements during this period. This dataset has also been used in some previous studies in the literature (e.g., Wang, et al., 2013a \& 2013b; Li-Ying et al., 2013; Li-Ying et al., 2014; Li-Ying and Wang, 2014).

Not all firms that license foreign technology necessarily collaborate with local R\&D partners, and not all firms that collaborate with local R\&D partners have homogeneous performance. Therefore, we first select a sample that (1) is well exposed to collaboration with local universities, research institutes, and industrial firms; and (2) remains randomly distributed with regard to firms' heterogeneous performance in the SIPO licensing database. Prior studies have reported that high-tech firms have a high propensity to collaborate with universities and other research institutes (Berger and Diez, 2004). Similarly, Pavitt (1984) found that science-based industries tend to have a relatively high likelihood of collaborating with universities and other industrial partners. Following these prior studies, this article focuses on the high-tech sectors in China (Liu and Zhi, 2010). According to the Chinese State Statistical Bureau's industrial classification system, the Chinese high-tech industries are divided into 17 sub-sectors under five main categories. Specifically, the high-tech industries include: medical and pharmaceutical products (with three sub-sectors), aircraft and spacecraft (with two sub-sectors), computer and office equipment (with three sub-sectors), medical 
equipment and meters (with two sub-sectors), and electronic and telecommunication equipment (with seven sub-sectors).

Next, we need to select a sample that is large enough for our research purposes and allows sufficient time for each licensee firm to 'learn' from previously licensed technology. Thus, given the availability of data, it is needed to limit the observation of foreign technology licensing to a specific time period and observe the behavior of firms after the year of licensing to observe licensee firms' technological innovation performance. This approach is in line with the literature. For instance, Hausman and Griliches (1984) find that the elasticity of patenting with respect to R\&D effort is five years. Likewise, Johnson (2002) suggests that the lag time between firms' licensing experiences from abroad and their innovation success is also five years. Ahuja and Katila (2001) report the positive effect that firms' mergers and acquisitions (M\&As) have on the patent applications that the firms made within five years after the M\&As took place. Thus, to be consistent with prior studies, the learning time is set as a five-year period after licensing of foreign patents. As a result, the licensing agreements that involved foreign technology in the high-tech sectors between 2000 and 2006 are analyzed, and then the technological innovation performance of these sample firms during the five years after licensing are measured. For example, if a firm licensed foreign technology in 2000, we expect that this firm should have learned and demonstrated improved innovation performance (which is measurable by calculating its patent applications in the following five years, i.e., from 2001 to 2005). Data on patent applications during the subsequent five-year period was also collected for each firm from the SIPO public data (see http://search.cnipr.com/). Overall, this analysis is conducted based on a sample of 160 Chinese licensee firms in the high-tech sectors during the period 2000-2006 and then observe their subsequent patent applications within the five-year period after licensing. Therefore, the latest year of observation for patent application is till 2011. Since a number of firms had more than one licensing agreement, in total there are 
176 firm-year observations, resulting in a cross-sectional study with a lagging effect on the dependent variable.

Information on firm age and firm size was not available from the SIPO licensing and patent application data. Thus, the complementary sources for this information, collected from newspaper articles and annual reports for the period of observation, were referred to. The firm age of all 160 sample firms was identified using this method without much difficulty, but the historical figure regarding firm size of 21 sample firms could not be found using this method. Eventually, we had to ask the firms about this missing information through phone calls and emails.

\section{Measures}

\section{Dependent variable}

Technological innovation performance: among the various measures of a firm's technological innovation performance, the two most widely used are new product sales and patent counts in a firm's patent portfolio. The former implies the product-market side of learning outcome, and the latter stresses technological advance, regardless of product sales. Both measures have advantages and disadvantages. Particularly, there are reasons to expect that using new product sales to measure technological innovation performance in China has an inherently severe bias, because firms with products qualified as 'new to the country' or 'new to the province' in China are eligible to receive various monetary subsidies or tax deductions from the provincial or central government. Therefore, Chinese firms tend to have a strong incentive to over-record their new product sales. Another fundamental problem is that 'newness' is neither evaluated by standardized criteria nor is it coordinated by a unified benchmarking system among provinces and municipalities ( $\mathrm{Li}, 2011)$. On the contrary, patent counts have been widely used in the strategic and innovation management literature (Pakes and Griliches, 1980; Trajtenberg, 1990). This is because patents contain reliable information that indicates (1) the making of 
inventions that are industrially useful and not obvious to an individual who is knowledgeable in the relevant technical field; (2) the ownership of intellectual property rights; (3) a firm's technological portfolio and strategy (Ernst, 2003); and (4) a firm's strategy for product market internationalization if international patents are applied (Ghemawat, 2003). Thus, patents are a reliable proxy for innovative outputs (Acs and Audretsch, 1989). Although it is true that patents cannot indicate a firm's capability in the product-market side of an innovation process (Ahuja and Katila, 2001; Griliches, 1992; Singh, 2008), they clearly represent a degree of newness in terms of technical improvement and methods of application that are new to a country. More importantly, the procedures and evaluation system of patent applications are standardized across all provinces and industries and remain constant over a relatively long time period $^{3}$. For these sound reasons, we believe that patent count is a better measure of technological innovation performance than new product sales. Thus in this study, a firm's technological innovation performance is measured as the total number of patent applications within the five-year period after the licensing year. Note that patent applications is used here rather than granted patents, because SIPO publishes patent data within several months after application, but patents may not be granted until several years later. Had granted patents been used in our analysis, a great number of observations would have been lost compared to using information on patent applications.

\section{Independent variables}

Foreign technology licensing is measured by the total number of licensed foreign patents in a firm's licensing contracts in a particular year.

Collaboration scale is measured by the total number of partners that co-patented with a licensee firm within the five-year period after the year of licensing foreign patents. Since we are interested in the facilitating role of collaboration, an observation window for 'collaboration scale' that moves in parallel with the observation of the technological 
innovation performance of firms is used. This approach allows timely synchronized interactions between the influence of partners and the active learning and innovating processes of firms after they license foreign technology.

In the literature on university-industry collaboration, patents are a popular information source to analyze the collaborative relationship between universities and industrial firms, where a technical invention draws intellectual inputs from a group of inventors and multiple inventors from universities and industrial firms are recorded on a patent application (Cohen et al., 2002; Owen-Smith et al., 2002; Leydesdorff, 2004). There are two options when patent data are used to measure 'collaboration scale': (1) the number of patents licensed by the sample firms from its local partners; or (2) the number of co-patenting between the licensee firms and its partners. There are several reasons why the latter method is preferred. First, multiple studies have confirmed the relatively low relevance of formal intellectual property transfer via licensing (compared to other types of interaction between universities and industries) (Cohen et al., 2002; Pavitt 1991; also see a review by Perkmann and Walsh, 2007). Second, technology transfer from universities takes place more evidently through informal networks between academics and industrial corporations than through the formal communication channels of technology licensing (Colyvas et al., 2002). This makes it very difficult to clearly divide intellectual properties between partners (Hagedoorn, 2003). Therefore, the literature recognizes co-patenting as a reliable indicator for the joint ownership of collaborative outcomes (Belderbos et al., 2014). A co-patented invention by multiple parties reliably stands for an organizational-level linkage through various forms of relationships regarding an invention of interest (Motohashi and Yun, 2007). For instance, a joint patent application by a university and a firm suggests that this invention has been achieved through a certain level of collaboration in research and/or development (Cohen et al., 2002). Furthermore, prior studies also found that firms engaged in collaborative activities in 
the past are more likely to adopt co-patenting in subsequent collaboration (Hagedoorn et al., 2003). For these reasons, co-patenting between firms and their collaborating partners may well represent the consequence of effective knowledge exchange and become a good proxy for the intellectual results derived from past collaboration. That is why the co-patenting information in the Chinese patent application system is used to trace the collaboration relationships between the licensee firms and their partners in our sample.

Collaboration scope measures the diversity of a focal firm's local R\&D partners. First the Herfindahl-Hirschman Index (HHI) for a focal firm is calculated to measure how 'concentrated' its local partner networks are. HHI is commonly used to measure market concentration, summing the squared term of each competitor's market share. It has also been used in the innovation management literature to measure the inventive concentration in a similar manner (Liston-Hayes and Pilkington, 2004). The formula of HHI is $H=\sum_{i=1}^{N} S_{i}^{2}$. For instance, if a firm had only one type of co-patenting partner, e.g., four universities, then the value of $\mathrm{HHI}$ is the sum of four times of $25 \%^{2}$, which equals ' 1 '. In a different case, if a firm collaborated with one university partner, two research institutes, and one firm partner, then its HHI will be $25 \%^{2}+50 \%^{2}+25 \%^{2}$, which equals ' 0.375 '. Thus, HHI has a theoretical range of $(0,1]$. Next, the HHI concentration measure is converted to the measure of collaboration scope by using the value of ' 1 minus HHI'. Thus, the value of 'collaboration scope' variable has a theoretical range of $[0,1)$, where ' 0 ' indicates there is only one type of local $R \& D$ partner(s) and a larger value indicates there are more types of local $R \& D$ partners for a focal firm ${ }^{4}$.

\section{Control variables}

Several variables that are commonly considered in the literature on innovation management are controlled for in this study. First, at the licensing portfolio level, we control for multiple license sources by using the variable licensor scale, which is measured as the number of 
licensors that a licensee firm had in a particular year of licensing. Next, license exclusiveness is used to reflect the influence of potential competitive pressure on firms' business activities. This variable is operationalized as the number of licensees whose license agreements contain the same patents from a licensor within the two-year period after the year of licensing (Dodgson, 1991). Second, at the firm level, four variables are controlled for: firm size, existing patent base, firm age, and export orientation. Firm size is measured as the number of employees (in a natural logarithm form) in a firm in a particular licensing year. Existing patent base is the cumulative number of Chinese patent applications of a firm within the fiveyear period prior to the year of licensing. This measure to some extent represents a firm's absorptive capacity before licensing technologies (Cohen and Levinthal, 1990). Firm age is measured as the number of years between the year when a firm was founded and the licensing year. Export orientation is measured as a dummy variable with a value of ' 1 ' if a firm explicitly states an export orientation in their annual report or if the majority of a firm's sales are made to the international market. Otherwise, the value of this variable is set as ' 0 '.

Next, several macro-level variables that account for the effects of external contingencies are controlled for: Province patent stock refers to the accumulative number of Chinese patent applications per million people in a licensee firm's local province within the five years after the licensing year. This variable controls for the differences in technological development across different provinces in China. The extant literature also suggests that it is important to control for a firm's industry sector, because firms in different sectors differ with respect to their strategic orientation and propensity to patent (Cohen et al., 2002). Thus, four industry dummies are included to control for the potential influence of industry difference on licensee firms' propensity to file patent applications. The electronic equipment and communications equipment sector was set as the default. Finally, considering China's rapid economic transition, a set of year dummy variables are employed to control for any other 
unobservable variances pertaining to a particular year within the period 2000-2006. The year 2000 was omitted as the reference year.

\section{Estimation procedure}

Our study uses patent counts to measure technological innovation performance. There are 176 yearly observations for 160 firms, meaning that 16 firms were observed more than once during this period with regard to their licensing activities. Among these repeatedly observed firms, the interwave spacing - the time distance between the repeated measures of the same firm - ranges from 2 to 5 years. Thus, our data structure is cross-sectional with repeated measures for some units and a lagged dependent variable.

Models for count data have been prominent in economics and management by using Poisson or negative binomial models (Cameron and Trivedi, 2005). However, most traditional methods, such as negative binomial models, are used for cross-sectional count data by considering repeated observations as independent observations. This approach might lead to biased and incorrect estimations (Liang and Zeger, 1986), because it cannot account for correlations due to repeated measures of the same unit if researchers still use the likelihood method to estimate the parameters (Greene, 2008; Hilbe, 2011). Thus, following some prior publications, a generalized estimating equation (GEE) method is used to estimate a negative binomial model (Chang and Jennifer, 2011; Katila and Ahuja, 2002). The GEE estimating method accounts for repeated observations by estimating the correlation structure of the error term. This method also has the advantage that it averages the marginal effects of the model across every case and can be easily used to account for unequal interwave spacing among repeatedly observed units (Ballinger, 2004). Moreover, GEE provides multiple correlation matrix structures to best match the data (Liang and Zeger, 1986). Prior work has shown that the 'exchangeable' matrix option, which will be used in this article, is more appropriate than 
fixed- or random-effects models (Hilbe, 2011). Additionally, to account for any overdispersion in the data, we report all results with robustness.

\section{Results}

The descriptive statistics and correlations between the variables are presented in Table 1 . Some variables have a large difference between the mean and the standard deviation. This confirms that negative binomial regression is appropriate for our analyses. The correlation between collaboration scale and scope is 0.75 , which is high enough to suspect if there could be a multicollinearity problem. Therefore, we conducted a robustness test, which shows that the results are consistent and unaffected by this high correlation between the variables. The variance inflation factor (vif) score is well below 4.90. Thus, the potential problem of multicollinearity is not a concern.

Insert Table 1 here

Table 2 presents the results of all estimated models using a GEE negative binomial regression analysis. Model 1 presents the basic model including only the control variables. In Model 2 the first main explanatory variable, foreign technology licensing, is introduced. In Models 3 and 5, collaboration scale and collaboration scope are introduced, respectively. In Models 4 and 6, the interaction terms between foreign technology licensing and collaboration scale and between foreign technology licensing and collaboration scope are introduced, respectively, to test the hypothesized moderating effects. Finally, a full model (Model 7) is added where all the main effect variables and interaction terms are included. All independent variables are standardized, but the dependent variable is not.

Insert Table 2 here 
Hypothesis 1 predicts that technology licensing from foreign origins is positively associated with a firm's technological innovation performance. We find that the coefficient for foreign technology licensing in Model 2 is positive and significant $(\beta=0.070, \mathrm{p}<0.05)$, and this effect remains consistent in all the following models as well. Thus, we find support for Hypothesis 1.

Next, Hypothesis 2 predicts that the scale of collaborations with local partners positively moderates the relationship between licensing foreign technologies and the licensee firm's subsequent technological innovation performance. Thus, foreign technology licensing and collaboration scale are added in Model 4. We find that the coefficients for foreign technology licensing and collaboration scale are positive and significant $(\beta=0.068, \mathrm{p}<0.10$; $\beta=0.152, \mathrm{p}<0.05$, respectively). Meanwhile, we also find that the coefficient for foreign technology licensing $*$ collaboration scale is positive and significant $(\beta=0.873, \mathrm{p}<0.10)$. Thus, Hypothesis 2 is supported.

Next, Hypothesis 3 predicts that the scope of collaborations with local partners positively moderates the relationship between licensing foreign technology and the licensee firm's subsequent technological innovation performance. Thus, foreign technology licensing and collaboration scope are added in Model 6. We find that the coefficient for foreign technology licensing and collaboration scope are positive and significant $(\beta=0.0508, \mathrm{p}<0.10$; $\beta=1.143, \mathrm{p}<0.10$, respectively). Meanwhile, we also find that the coefficient for foreign technology licensing ${ }^{*}$ collaboration scale is positive and significant $(\beta=0.831, \mathrm{p}<0.01)$. Thus, Hypothesis 3 is also supported.

Model 7 is the full model, in which all variables and interaction terms are included to check to what extent the hypothesized moderating effects will be 'diluted' by having both interaction terms included. We find that the coefficient for foreign technology licensing, collaboration scale, and collaboration scope are still positive and significant $(\beta=0.0689$, 
$\mathrm{p}<0.01 ; \beta=0.151, \mathrm{p}<0.10 ; \beta=1.888, \mathrm{p}<0.10$; respectively). Interestingly, the two interaction terms, foreign technology licensing*collaboration scale and foreign technology licensing ${ }^{*}$ collaboration scale still remain positive and significant $(\beta=0.335, \mathrm{p}<0.10 ; \beta=0.800$, $\mathrm{p}<0.01$; respectively). Thus, the moderating effects of collaboration scale and scope are confirmed.

Although the control variables are not our central concern in this article, some findings are still worth mentioning. First, a firm's accumulation of technological knowledge, measured by its existing patent base, is positively associated with its future technological innovation performance. This finding is in line with our expectation based on the literature about absorptive capacity. Second, firm size and firm age also show positive and significant effects, meaning that incumbent large firms in our sample performed better than small and young firms with regard to technological innovation. However, this finding should be interpreted with caution, because it is likely that incumbent large firms have more financial resources to spend on patenting, while small and young firms are usually limited in capital so they will seek alternative ways to protect their intellectual property.

\section{Discussion}

\section{About the findings and contributions}

This article addresses a theoretically underdeveloped area in the relational view by positioning two sets of external relationships of focal firms against each other and trying to find the relations among these relationships. The results of hypothesis testing show that Chinese licensee firms' technological innovation performance is positively associated with their licensing of foreign technologies (H1). A learning effect from foreign technological resources is evident. We also find that licensed foreign technology as an external resource is more likely to contribute to generating internal and relational rents for a licensee firm if the firm has a large scale and a broad scope of local R\&D collaboration (H2 and H3). Even 
though the competencies and trustworthiness of each local partner were not able to be taken into account, the positive moderating effects of local R\&D collaboration scale and scope are significant enough to confirm that a focal firm's collection and combination of local R\&D network matters for the creation of synergetic relations among different sources of knowledge as resources.

Our findings shed light on several theoretical streams in the literature. First, it extends the relational view by conceptualizing how externally acquired resources from one set of external relationships can be internalized, shared, and absorbed by focal firms with the help of shared and non-shared resources of another set of external partners to generate appropriated relational rent and inbound spillover rent. In this way, resources gained from different external relationships can be understood in relation to each other. Second, our study supports the argument regarding a firm's open innovation practices through external knowledge acquisition within the context of technology and economic catch-up. Firms must combine disparate knowledge resources from domestic and foreign origins to develop technological innovations (Fu and Gong, 2011; Liefner et al., 2006; Mathews and Cho, 1999). Specifically, we find that Chinese high-tech firms rely on foreign technologies and knowledge generated by local partners at the same time. Local collaborations need to be large not only in scale but also in scope. In this way, the value for future innovation by learning from foreign technology can be less constrained by the limited absorptive capacity of focal firms (Furman et al., 2006; Zucker et al., 1998; van Dijk and Bell, 2007).

Our findings have managerial implications as well. From an open innovation perspective (Chesbrough, 2003), our study suggests that to enhance their competitiveness, firms may expand their knowledge base by linking with multiple local partners on a large scale and with a broad scope and trying to reap a synthetic effect on technological innovation by combining foreign technology with domestic technological resources. Nevertheless, the 
management of inter-firm relationships and external resources thereof is after all a mandate for innovation managers, who often struggle with convincing the top management of the firm to make continuous commitment to ensure a large-scale and broad-scope of local $\mathrm{R} \& \mathrm{D}$ collaboration network. These demanding tasks do not always receive equal attention from the top management if they are raised separately from other issues prioritized by the top management. In this respect, if making the most out of the licensed foreign technology is assumed by the top management, our study empowers innovation managers to formulate a sound and convincing logic, suggesting that to realize the full potential of accessing foreign technologies, a firm has to enlarge routinely its exposure to local knowledge partners in addition to develop internal capabilities. This logic can also be extended into a management principle that requires managers to relate inter-firm relationships and external resources in an integrated manner, rather than managing each type of patterns separately.

\section{About generalizability}

Although the empirical base in this study is evidence from Chinese firms, the findings can be generalized to firms in other countries in a similar context, which refers to at least two factors. First, the inefficiency and ineffectiveness of Chinese industrial R\&D during the 1980s and 1990s left China lagging behind compared to other industrialized countries (Xue, 1997). Chinese firms often exploit the advantage of their late arrival by tapping into technology developed by firms in advanced economies without having to replicate the entire technological trajectory. Thus, they can accelerate their uptake and learning efforts through various international technology diffusion channels, including technology licensing from foreign origins, which has been promoted in China as a primary means of addressing the country's technological deficiencies (Mathews and Cho, 1999; Sun and Du, 2010; Wang and Li-Ying, 2014). Since countries develop relatively stable and distinct trajectories of technological specialization (Le Bas and Sierra, 2002) and demonstrate different institutions 
(Zhu et al., 2012), it is possible that the role of $R \& D$ collaboration with local partners in developing countries is likely to function with unique patterns (Yusuf, 2008). Thus, the findings might be generalized to other countries that share technological and economic development trajectories similar to those of China. These include, for instance, the rest of the BRIC countries and other developing countries because they have been in a relatively lagging position with regard to economic and technological development. Such a lagging position determines the types of foreign technologies that they are interested in and the incentives to catch up with the help of local R\&D collaboration. However, this is not to say that the findings are not applicable to advanced economies at all. Rather, we expect that there will be a difference in degree with regard to how various types of networks interact.

Second, the generalizability of our findings will be high if, in another country, universities, research institutes, and industrial firms function in a way similar to those of China. This is related to their roles within the institutions of a specific nation. For instance, in many Western advanced economies, universities and research institutes are considered to be in the same category of knowledge partners for firms (van Beers et al., 2008; Miotti and Sachwald, 2003). However, in China, they are quite different: the quality of research at universities is much better than in research institutes, and local universities generally possess a relatively higher level of scientific knowledge, technology, and technical services (Zhou, 2012). Meanwhile, research institutes are mostly not qualified as universities but receive public and/or private funding for research into relatively specific technological areas applied to industries (Gill and Mulvenon, 2002). They include, for instance, all national- or provincial-level research institutes and laboratories in the fields of aerospace, agriculture, aquaculture, military, petroleum, etc. According to the China Science and Technology Statistics Data Book 2007, the shares of R\&D expenditures for universities and research institutes are being sustained and decreasing, respectively (Guan et al., 2005). In addition, 
universities and research institutes conduct R\&D differently. Since the economic reform was undertaken in China, universities have become mostly oriented toward basic research, while research institutes now focus on industrial technology development and marketable applications of technology. Chinese research institutes are becoming increasingly industrialized and commercialized. Therefore, we suggest that the findings in this article can be generalized only to other countries where it is conceptually and practically possible to distinguish the difference between universities and research institutes.

\section{Limitations and future research}

The findings, in combination with the conceptual framework, suggest a solid basis for future research to investigate the relations among focal firms' relationships in more sophisticated ways. However, our study certainly has some other limitations that could inspire future research. First, this article focused only on firms that licensed foreign technology, but there are many other channels through which firms can access foreign technology, e.g., an equity alliance with or the merger and acquisition of a foreign firm that holds the technology of interest. Future research should investigate these alternative channels of accessing foreign technology. Second, co-patenting is used as a proxy for collaboration, which can be the result of various types of collaborations, including informal ones. This approach inevitably overlooked many detailed relational linkages among local R\&D collaborations. Future research should investigate the possible differences between various forms of collaboration on firms' technological innovation performance. For instance, collaborations with little relational involvement and highly relational involvement can function differently with respect to facilitating innovation based on technologies licensed from elsewhere. The former usually include direct technology transfer contractual relationships, while the latter include situations in which individuals and teams from the focal firm and the partner organizations work together on specific projects and produce common outputs (Perkmann and Walsh, 2007; 
Wright et al., 2008). Next, due to the limitation of our data, it was not possible to identify whether a licensed technology was shared with partners or not in this article. Remedies for this issue in future research can surely yield more valuable insights and contribute to theory building. Furthermore, our sample firms are those in the Chinese high-tech sector, which are knowledge-intensive and have benefited to a great extent from various subsidies from the Chinese government. Thus, the extent to which our findings can be generalized to other industrial sectors remains uncertain. Future research should extend its scope to examine other industrial sectors. Finally, three types of local R\&D partners, i.e., universities, research institutes, and industrial firms, were treated as three homogenous groups. Future research may also investigate the nuance in the variance within each group if there are systematic differences. For instance, one can distinguish public universities and downstream industrial partners from private universities and upstream industrial partners, respectively. Overall, greater effort following this research direction is needed to advance the theoretical foundation of performance difference by exploring the relations among the various sets of firm relationships from the relational view.

\section{Conclusion}

This article situates itself in an underdeveloped research niche in a relational view with respect to the contribution of interrelated external resources from non-overlapping sources on firms' innovation performance. Our findings, on the one hand, are consistent with prior studies suggesting that technology licensing may function as a major knowledge resource contributing to a firm's technological innovation. On the other hand, when firms with limited internal resources and absorptive capacity rely on licensing foreign technology, local $\mathrm{R} \& \mathrm{D}$ collaboration plays an important moderating role that to a great extent facilitates the absorption, adaptation, assimilation and diffusion of the in-sourced foreign technology and generates relational rents. Our empirical analysis supported our hypotheses regarding the roles 
of local R\&D collaboration on foreign technology licensing in China. These findings underpin the most important mechanisms behind the development of firms' innovation capabilities and extend the current form of the relational view. 


\section{Endnotes}

1. By technological innovation performance, this article specifically refers to the technological side of innovation, which can be measured by, for instance, patent applications.

2. As we focus on the competitive advantages and performance of a focal firm, the outbound spillover effect, which is included in Lavie's (2006) model but eventually benefits the partners, is not discussed in this study.

3. Another criticism is that Chinese firms may receive subsidies to apply for new patents, thus the number of patent applications might be inflated in general, but such an inflation bias will be equally distributed among the sample firms and thus can be safely disregarded.

4. We also tried to use a measure of scope by simply calculating the number of unique types of collaborators. This becomes an ordinal measure with a value varying from ' 1 ' to ' 3 '. The results of using this simple ordinal measure for collaboration scope were not significantly different from the ones that we report in the article, using the value of 1 minus HHI. Thus, the robustness of the results for collaboration scope is strong. 


\section{References}

Acemoglu, D. 2002. Directed technological change. Review of Economic Studies 69 (4): 781810.

Acs, Z. J. and D. B. Audretsch. 1989. Patents as a Measure of Innovative Activity. Kyklos 42(2): 171-180.

Agrawal, A. K. 2001. University-to-industry knowledge transfer: literature review and unanswered questions. International Journal of Management Reviews 3(4): 285-302.

Ahrweiler, P., A. Pyke, and N. Gilbert. 2011. A new model for university-industry links in knowledge-based economics. Journal of Production Innovation Management 28: 218235.

Ahuja, G. and R. Katila. 2001. Technological acquisitions and the innovation performance of acquiring firms: A longitudinal study. Strategic Management Journal 22(3): 197-220.

Arora, A. 1996. Contracting for tacit knowledge: The provision of technical services in technology licensing contracts. Journal of Development Economics 50: 233-256.

Arrow, K. J. 1962. Studies in applied probability and management science. Stanford, California: Stanford University Press.

Ballinger, G. A. 2004. Using Generalized Estimating Equations for Longitudinal Data Analysis. Organizational Research Methods 7(2): 127-150.

Barney, J. 1991. Firm resources and sustained competitive advantage. Journal of Management 17(1): 99-120.

Belderbos, R., M. Carree, and B. Lokshin. 2004. Cooperative R\&D and firm performance. Research Policy 33(10):1477-1492.

Belderbos, R., B. Cassiman, D. Faems, B. Leten, and B.van Looy. 2014. Co-ownership of intellectual property: Exploring the value-appropriation and value-creation implications of co-patenting with different partners. Research Policy 43: 841-852.

Berger, M. and J. R. Diez. 2004. Technological capabilities and innovation in Southeast Asia: Results from innovation surveys in Singapore, Penang and Bangkok. Science, Technology \& Society 11: 109-148.

Burt, R. S. 1992. Structure Holes: The Social Structure of Competition. Harvard University Press, Cambridge, MA.

Cameron, C. and P. Trivedi. 2005. Microeconometrics: Methods and applications. Cambridge: Cambridge University Press.

Chang, H.-O. and O. Jennifer. 2011. Multinationals' response to major disasters: How does subsidiary investment vary in response to the type of disaster and the quality of country governance? Strategic Management Journal 32(6): 658-681.

Chatterji, D. and T. A. Manuel. 1993. Benefiting from external sources of technology. Research Technology Management 36(6): 21-27. 
Chen, X. and C. Sun. 2000. Technology transfer to China: Alliances of Chinese enterprises with western technology exporters. Technovation 20(7): 353-362.

Chesbrough, H. W. 2003. Open innovation: The new imperative for creating and profiting from technology. Boston, Mass: Harvard Business School Press.

Chiaroni, D., V. Chiesa and F. Frattini. 2010. Unraveling the process from Closed to Open Innovation: Evidence from mature, asset-intensive industries. $R \& D$ Management 40: 222-245.

Cohen, W. M. and D. A. Levinthal. 1990. Absorptive capacity: A new perspective on learning and innovation. Administrative Science Quarterly 35: 128-152.

Cohen, W. M., R. R. Nelson, and J. P. Walsh. 2002. Links and impacts: The influence of public research on industrial R\&D. Management Science 48(1): 1-23.

Colyvas, J., M. Crow, A. Gelijns, R. Mazzoleni, R. Nelson, N. Rosenberg, and B. Sampat. 2002. How do university inventions get into practice? Management Science 48(1): 6172.

Deolalikar, A. B. and R. E. Evenson. 1989. Technology production and technology purchase in Indian industry: An econometric analysis. Review of Economic Studies 71(4): 687692.

Desai, A. V. 1988. Technology absorption in Indian industry. New Delhi: Wiley Eastern.

Dodgson, M. 1991. Technology learning, technology strategy and competitive pressures. British Journal of Management 2(3): 132-149.

Dodgson, M. 1992. The strategic management of R\&D collaboration. Technology Analysis \& Strategic Management 4(3): 227-244.

Dyer, J. H. and H. Singh. 1998. The relational view: Cooperative strategy and sources of interorganizational competitive advantage. Academy of Management Review 23(4): 660-679.

Ernst, H. 2003. Patent information for strategic technology management. World Patent Information 25: 233-242.

Fleming, L. 2001. Recombinant uncertainty in technological search. Management Science 47(1): 117-132.

Fontana, R., A. Geuna, and M. Matt. 2006. Factors affecting university-industry R\&D projects: The importance of searching, screening and signaling. Research Policy 35(2): 309-323.

Foss, N. J., J. Lyngsie, and S. A. Zahra. 2013. The role of external knowledge sources and organizational design in the process of opportunity exploitation. Strategic Management Journal, 34(12): 1453-1471.

$\mathrm{Fu}, \mathrm{X}$. and Y. Gong. 2011. Indigenous and foreign innovation efforts and drivers of technological upgrading: evidence from China. World Development 39(7): 1213-1225. 
Furman, J. L., M. K. Kyle, I. M. Cockburn, and R. Henderson. 2006. Public and Private Spillovers, Location and the Productivity of Pharmaceutical Research. National Bureau of Economic Research No. w12509.

Gill, B. and J. Mulvenon. 2002. Chinese military related think tanks and research institutions. The China Quarterly 171: 617-624.

Ghemawat, P. 2003. Semiglobalization and international business strategy. Journal of International Business Studies 34(2): 138-152.

Greene, W. 2008. Functional forms for the negative binomial model for count data. Economics Letters 99(3): 585-590.

Griliches, Z. 1992. The search for R\&D spillovers. Scandinavian Journal of Economics 94: S29-S47.

Guan, J. C., R. C. M. Yam, and C. K. Mok. 2005. Collaboration between industry and research institutes/universities on industrial innovation in Beijing, China. Technology Analysis \& Strategic Management 17(3):339-353.

Gulati, R. and H. Singh. 1998. The architecture of cooperation: Managing coordination costs and appropriation concerns in strategic alliances. Administrative Science Quarterly 43(4): 781-814.

Gulati, R. 1999. Network location and learning: The influence of network resources and firm capabilities on alliance formation. Strategic Management Journal 20:397-420.

Hagedoorn, J. 2003. Sharing intellectual property rights - An exploratory study of joint patenting amongst companies. Industrial and Corporate Change 12: 1035-1050.

Hagedoorn, J., H. Van Kranenburg, and R.N. Osborn. 2003. Joint patenting amongst companies: exploring the effects of inter-firm R\&D partnering and experience. Managerial and Decision Economics 24: 71-84.

Hausman, J. A. and Z. Griliches. 1984. Econometric models for count data with an application to the patents-R\&D relationship. Economic and Political Weekly 27: 909938.

Henderson, R., A. Jaffe, and M. Trajtenberg. 1998. Universities as a source of commercial technology: A detailed analysis of university patenting 1965-1988. Review of Economic and Statistics 80: 119-127.

Hershberg, E., K. Nabeshima, and S. Yusuf. 2007. Opening the Ivory Tower to business: University-industry linkages and the development of knowledge-intensive clusters in Asian cities. World Development 35(6): 931-940.

Hilbe, J. M. 2011. Negative Binomial Regression (Second ed.). Cambridge: Cambridge University Press.

Jiang, R.J., Tao, Q. T., and Santoro, M. D. 2010. Alliance portfolio diversity and firm performance. Strategic Management Journal 31: 1136-1144.

Johnson, D. K. N. 2002. 'Learning-by-licensing': R\&D and technology licensing in Brazilian invention. Economics of Innovation \& New Technology 11(3): 163-177. 
Katila, R. and G. Ahuja. 2002. Something old, something new: A longitudinal study of search behavior and new product introduction. Academy of Management Journal 45(6): 1183-1194.

Katrak, H. 1990. Imports of technology and the technological effort of Indian enterprises. World Development 18(3): 371-381.

Knudsen, M. P. 2007. The relative importance of interfirm relationships and knowledge transfer for new product development success. Journal of Product Innovation Management 24: 117-138.

Kodama, T. 2008. The role of intermediation and absorptive capacity in facilitating university-industry linkages - An empirical study of TAMA in Japan. Research Policy 37(8): 1224-1240.

Kogut, B. and U. Zander. 1992. Knowledge of the firm, combinative capabilities, and the replication of technology. Organization Science 3(3): 383-397.

Kumar, N. 1987. Technology imports and local research and development in Indian manufacturing. The Developing Economies 25(3): 220-233.

Laursen, K. and A. Salter. 2006. Open for innovation: The role of openness in explaining innovation performance among UK manufacturing firms. Strategic Management Journal 27: 131-150.

Lavie, D. 2006. The competitive advantage of interconnected firms: an extension of the resource-based view. Academy of Management Review 31(3): 638-358.

Lavie, D. and Rosenkopf, L. 2006. Balancing exploration and exploitation in alliance formation. Academy of Management Journal 49(4): 797-818.

Leone, M. I. and T. Reichstein. 2012. Licensing fosters rapid innovation! The effect of the grant-back-clause and technological unfamiliarity. Strategic Management Journal 33(8): 965-985.

Le Bas, C. B. and C. Sierra. 2002. Location versus home country advantages in R\&D activities: Some further results on multinationals locational strategies. Research Policy 31: 589-609.

Lehrer, M., P. Nell, and L. Gärber. 2009. A national systems view of university entrepreneurialism: Inferences from comparison of the German and US experience. Research Policy 38(2): 268-280.

Leydesdorff, L. 2004. The university-industry knowledge relationship: Analyzing patents and the science base of technologies. Journal of the American Society for Information Science and Technology 55(11): 991-1001.

Li, J. and R. K. Kozhikode. 2008. Knowledge management and innovation strategy: The challenge for latecomers in emerging economies. Asia Pacific Journal of Management 25(3): 429-450.

Li, J. and R. K. Kozhikode. 2009. Developing new innovation models: Shifts in the innovation landscapes in emerging economies and implications for global R\&D management. Journal of International Management 15(3): 328-339. 
Li, J. 2010. Global R\&D alliances in China: Collaboration with universities and research institutes. IEEE Transactions on Engineering Management 57(1):78-87.

Li, X. 2011. Sources of external technology, absorptive capacity, and innovation capability in Chinese state-owned high-tech enterprises. World Development 39(7): 1240-1248.

Li, Y. and W. Vanhaverbeke. 2009. The Effects of Inter-industry and Country Difference in Supplier Relationships on Pioneering Innovations. Technovation 29:843-858.

Liang, K.-Y. and S. L. Zeger. 1986. Longitudinal data analysis using generalized linear models. Biometrika 73(1): 13-22.

Liefner, I., S. Hennemann, and X. Lu. 2006. Cooperation in the innovation process in developing countries: Empirical evidence from Beijing Zhongguancun. Environment and Planning 38(1): 111-130.

Lin, B.-W. 2003. Technology transfer as technological learning: A source of competitive advantage for firms with limited R\&D resources. $R \& D$ Management 33(3): 327-341.

Liston-Hayes, C. and A. Pilkington. 2004. Inventive concentration: An analysis of fuel cell patents. Science and Public Policy 31(1): 15-25.

Liu, X. and T. Zhi. 2010. China is catching up in science and innovation: The experience of the Chinese Academy of Sciences. Science and Public Policy 37(5): 331-342.

Li-Ying, J., Y. Wang, S. Salomo, and W. Vanhaverbeke. 2013. Have Chinese firms learnt from their prior technology in-licensing? An analysis based on patent citations. Scientometrics 95(1):183-195.

Li-Ying, J., Y. Wang, and S. Salomo. 2014. An inquiry on external technology search through patent in-licensing and firms' technological innovations: Evidence from China. $R \& D$ Management 44(1): 53-74.

Li-Ying, J. and Y. Wang. 2014. Find them home or abroad? The relative contribution of international technology in-licensing to the 'indigenous innovation' in China. Long Range Planning DOI: 10.1016/j.lrp.2014.03.001, in press.

Madanmohan, T. R., U. Kumar, and V. Kumar. 2004. Import-led technological capability: A comparative analysis of Indian and Indonesian manufacturing firms. Technovation 24(12): 979-993.

Mathews, J. A. and D. S. Cho. 1999. Combinative capabilities and organizational learning in latecomer firms: The case of the Korean semiconductor industry. Journal of World Business 34(2): 139-156.

Miotti, L. and F. Sachwald. 2003. Co-operative R\&D: why and with whom? An integrated framework of analysis. Research Policy 32(8): 1481-1499.

Motohashi, K. and X. Yun. 2007. China's innovation system reform and growing industry and science linkages. Research Policy 36(8): 1251-1260.

Mowery, D. C. and S. Shane. 2002. Introduction to the special issue on university entrepreneurship and technology transfer. Management Science 48: v-ix. 
Nelson, R. R. and S. G. Winter. 1982. An evolutionary theory of economic change. Boston: Belknap Press of Harvard University Press.

Nooteboom, B. 2004. Inter-firm Collaboration, Learning and Networks: An Integrated Approach. London: Routledge.

Owen-Smith, J., M. Riccaboni, F. Pammolli, and W. W. Powell. 2002. A comparison of U.S. and European university-industry relations in the life sciences. Management Science 48(1):24-43.

Pakes, A. and Z. Griliches. 1980. Patents and R\&D at the firm level: A first report. Economics Letters 5(4): 377-381.

Palay, T. 1984. Comparative Institutional Economics: The Governance of Rail Freight Contracting. Journal of Legal Studies 13:265-288.

Pavitt, K. 1984. Sectoral patterns of technical change: Towards a taxonomy and a theory. Research Policy 13: 343-373.

Pavitt, K. 1991. What makes basic research economically useful? Research Policy 20: 109_ 119.

Perkmann, M. and K. Walsh. 2007. University-industry relationships and open innovation: Towards a research agenda. International Journal of Management Reviews 9(4): 259280.

Podolny, J. M. 2001. Networks as the pipes and prisms of the market. American Journal of Sociology 107(1): 33-60.

Ponds, R., F. van Oort, and K. Frenken. 2010. Innovation, spillovers and university-industry collaboration: an extended knowledge production function approach. Journal of Economic Geography 10(2): 231-255.

Schumpeter, J. A. 1934. The Theory of Economic Development. Cambridge, MA: Harvard University Press.

Scott-Kemmis, D. and M. Bell. 1985. Technological dynamism and technological content of collaboration: Are Indian firms missing opportunities? Economic and Political Weekly 20(45/47): 1991-2004.

Sherwood, A. L. and J. G. Covin. 2008. The formation of fairness perceptions in the cooperation between entrepreneurs and universities. Journal of Product Innovation Management 25:162-179.

Singh, J. 2008. Distributed R\&D, cross-regional knowledge integration and quality of innovative output. Research Policy 37(1): 77-96.

Stuart, T. E. and J. M. Podolny. 1996. Local search and the evolution of technological capabilities. Strategic Management Journal 17 (S1): 21-38.

Sun, Y. and D. Du. 2010. Determinants of industrial innovation in China: Evidence from its recent economic census. Technovation 30: 540-550.

Trajtenberg, M. 1990. A penny for your quotes: Patent citations and the value of innovations. RAND Journal of Economics 21(1): 172-187. 
Tsai, K.-H. and J.-C. Wang. 2007. Inward technology licensing and firm performance: A longitudinal study. $R \& D$ Management 37(2): 151-160.

Un, C. A., A. Cuervo-Cazurra, and K. Asakawa. 2010. R\&D collaboration and product innovation. Journal of Product Innovation Management 27: 673-689.

van Beers, C., E. Berghäll, and T. Poot. 2008. R\&D internationalization, R\&D collaboration and public knowledge institutions in small economies: Evidence from Finland and the Netherlands. Research Policy 37(2): 294-308.

van Beers, C. and F. Zand. 2014. R\&D Cooperation, partner diversity, and innovation performance: An empirical analysis. Journal of Product Innovation Management 31(2): 292-312.

van Burg, E., V. A. Gilsing, I. M. Reymen, and A. G. L. Romme. 2013. The formation of fairness perceptions in the cooperation between entrepreneurs and universities. Journal of Product Innovation Management 30(4): 677-694.

Van de Vrande, V., C. Lemmens, and W. Vanhaverbeke. 2006. Choosing governance modes for external technology sourcing. R\&D Management 36(3): 347-363.

van Dijk, M. and M. Bell. 2007. Rapid growth with limited learning: Industrial policy and Indonesia's pulp and paper industry. Oxford Development Studies 35(2): 149-169.

Vanhaverbeke, W., G. Duysters, and N. Noorderhaven. 2002. External technology sourcing through alliances or acquisitions: An analysis of the application-specific integrated circuits industry. Organization Science 13: 714-733.

Wang, Y., N. Roijakkers, and W. Vanhaverbeke. 2013a. Learning-by-Licensing: How Chinese Firms Benefit From Licensing-In Technologies. IEEE Transactions on Engineering Management 60(1), 46-58.

Wang, Y., Z. Zhou, J. Li-Ying. 2013b. The impact of licensed knowledge attributes on innovation performance of licensee firms: Evidence from Chinese electronic industry. Journal of Technology Transfer 38(5): 699-715.

Wang, Y. and Z. Zhou. 2013. The dual role of local sites in assisting firms with developing technological capabilities: Evidence from China. International Business Review 22(1): 63-76.

Wang, Y. and J. Li-Ying. 2014. When does inward technology licensing facilitate firms' NPD performance? A contingency perspective. Technovation, 34(1): 44-53.

Williamson, O. E. 1975. Markets and Hierarchies: Analysis and Anti-trust Implications. New York: The Free Press, NY.

Wright, M., B. Clarysse, A. Lockett, and M. Knockaert. 2008. Mid-range universities' linkages with industry: Knowledge types and the role of intermediaries. Research Policy 37(8): 1205-1223.

Xue, L. 1997. A historical perspective of China's innovation system reform: A case study. Journal of Engineering and Technology Management 14(1): 67-81. 
Yusuf, S. 2008. Intermediating knowledge exchange between universities and businesses. Research Policy 37(8): 1167-1174.

Zhou, W. 2012. Determinants and effects of research partnerships in China's emerging market. Contemporary Economic Policy 30(1): 129-147.

Zhu, Y., X. Wittmann, and M. Peng. 2012. Institution-based barriers to innovation in SMEs in China. Asia Pacific Journal of Management 29(4): 1131-1142.

Zucker, L. G., M. R. Darby, and J. Armstrong. 1998. Geographically Localized Knowledge: Spillovers or Markets? Economic Inquiry 36: 65-86. 
Table 1: Descriptive statistics and correlations

\begin{tabular}{|c|c|c|c|c|c|c|c|c|c|c|c|c|}
\hline Variable & Mean & SD & $\mathbf{1}$ & 2 & 3 & 4 & 5 & $\overline{6}$ & 7 & 8 & 9 & 10 \\
\hline 1. Tech. Inno. Performance & 344.88 & 1589.07 & - & & & & & & & & & \\
\hline 2. Foreign technology licensing & 2.89 & 1.30 & 0.15 & - & & & & & & & & \\
\hline 3. Firm age & 9.63 & 7.75 & 0.16 & 0.02 & - & & & & & & & \\
\hline 4. Existing patent base & 34.53 & 154.01 & 0.51 & 0.06 & 0.22 & - & & & & & & \\
\hline 5. Firm size & 3.20 & 0.60 & 0.22 & -0.04 & 0.24 & -0.06 & - & & & & & \\
\hline 6. Province patent stock & 4.48 & 0.38 & 0.06 & 0.07 & -0.12 & 0.03 & -0.16 & - & & & & \\
\hline 7. License exclusiveness & 23.64 & 11.59 & -0.16 & -0.13 & -0.06 & -0.13 & 0.15 & 0.05 & - & & & \\
\hline 8. Licensor scale & 1.18 & 0.43 & 0.08 & -0.01 & 0.01 & -0.03 & 0.01 & 0.02 & 0.08 & - & & \\
\hline 9. Export oritation & 0.35 & 0.48 & -0.16 & 0.11 & -0.16 & -0.13 & -0.04 & -0.03 & 0.01 & 0.01 & - & \\
\hline 10. Collaboration scale & 1.33 & 1.64 & 0.07 & -0.02 & 0.10 & 0.09 & 0.03 & -0.02 & -0.04 & 0.04 & 0.16 & - \\
\hline 11. Collaboration scope & 0.09 & 0.20 & 0.02 & -0.00 & 0.14 & 0.01 & 0.15 & -0.01 & -0.01 & 0.07 & 0.08 & 0.75 \\
\hline
\end{tabular}

Note. Number of observation $=176 ;$ Number of firms $=160$ 
Table 2: Negative binominal regression analysis results, using GEE estimation method ${ }^{\text {a, b, c, d }}$

\begin{tabular}{|c|c|c|c|c|c|c|c|}
\hline Variables & $\begin{array}{c}\text { Model 1 } \\
\text { Tech. Inno. } \\
\text { Performance }\end{array}$ & $\begin{array}{c}\text { Model } 2 \\
\text { Tech. Inno. } \\
\text { Performance }\end{array}$ & $\begin{array}{c}\text { Model } 3 \\
\text { Tech. Inno. } \\
\text { Performance }\end{array}$ & $\begin{array}{c}\text { Model } 4 \\
\text { Tech. Inno. } \\
\text { Performance }\end{array}$ & $\begin{array}{c}\text { Model } 5 \\
\text { Tech. Inno. } \\
\text { Performance }\end{array}$ & $\begin{array}{c}\text { Model 6 } \\
\text { Tech. Inno. } \\
\text { Performance }\end{array}$ & $\begin{array}{c}\text { Model } 7 \\
\text { Tech. Inno. } \\
\text { Performance }\end{array}$ \\
\hline Constant & $\begin{array}{c}8.070 * * * \\
(2.469)\end{array}$ & $\begin{array}{c}7.895 * * * \\
(2.397)\end{array}$ & $\begin{array}{c}7.835 * * * \\
(2.381)\end{array}$ & $\begin{array}{c}8.061 * * * \\
(2.324)\end{array}$ & $\begin{array}{l}8.128 * * * \\
(2.336)\end{array}$ & $\begin{array}{l}8.040 * * * \\
(2.218)\end{array}$ & $\begin{array}{c}7.567 * * * \\
(2.555)\end{array}$ \\
\hline Existing patent base & $\begin{array}{c}0.010 * * * \\
(0.001)\end{array}$ & $\begin{array}{c}0.010 * * * \\
(0.001)\end{array}$ & $\begin{array}{c}0.010 * * * \\
(0.001)\end{array}$ & $\begin{array}{c}0.010 * * * \\
(0.001)\end{array}$ & $\begin{array}{l}0.00989 * * * \\
(0.000592)\end{array}$ & $\begin{array}{l}0.0111^{* * * *} \\
(0.000748)\end{array}$ & $\begin{array}{l}0.0116 * * * \\
(0.000593)\end{array}$ \\
\hline Firm size & $\begin{array}{c}1.249 * * * \\
(0.229)\end{array}$ & $\begin{array}{c}1.266^{* * * *} \\
(0.224)\end{array}$ & $\begin{array}{c}1.263 * * * \\
(0.225)\end{array}$ & $\begin{array}{c}1.337 * * * \\
(0.274)\end{array}$ & $\begin{array}{l}-0.283 \\
(0.231)\end{array}$ & $\begin{array}{l}-0.372 \\
(0.274)\end{array}$ & $\begin{array}{c}1.311 * * * \\
(0.251)\end{array}$ \\
\hline Firm age & $\begin{array}{c}0.064 * * * \\
(0.022)\end{array}$ & $\begin{array}{c}0.067 * * * \\
(0.021)\end{array}$ & $\begin{array}{c}0.067 * * * \\
(0.021)\end{array}$ & $\begin{array}{c}0.071 * * * \\
(0.023)\end{array}$ & $\begin{array}{l}0.0627 * * * \\
(0.0202)\end{array}$ & $\begin{array}{l}0.0695 * * * \\
(0.0208)\end{array}$ & $\begin{array}{c}0.0650 * * * \\
(0.0183)\end{array}$ \\
\hline Province patent stock & $\begin{array}{c}0.923 * * \\
(0.390)\end{array}$ & $\begin{array}{c}0.854 * * \\
(0.381)\end{array}$ & $\begin{array}{c}0.846 * * \\
(0.378)\end{array}$ & $\begin{array}{c}0.786 * * \\
(0.358)\end{array}$ & $\begin{array}{l}-0.868 * * \\
(0.371)\end{array}$ & $\begin{array}{l}-0.808 * * \\
(0.332)\end{array}$ & $\begin{array}{c}0.787 * * \\
(0.319)\end{array}$ \\
\hline License exclusiveness & $\begin{array}{c}-0.060 * * * \\
(0.017)\end{array}$ & $\begin{array}{c}-0.060 * * * \\
(0.017)\end{array}$ & $\begin{array}{c}-0.060 * * * \\
(0.017)\end{array}$ & $\begin{array}{l}-0.037 * \\
(0.022)\end{array}$ & $\begin{array}{l}-0.0598 * * * \\
(0.0157)\end{array}$ & $\begin{array}{l}-0.0411 * * \\
(0.0196)\end{array}$ & $\begin{array}{c}-0.0576 * * * \\
(0.0151)\end{array}$ \\
\hline Licensor scale & $\begin{array}{c}0.085 \\
(0.286)\end{array}$ & $\begin{array}{l}-0.052 \\
(0.256)\end{array}$ & $\begin{array}{l}-0.065 \\
(0.251)\end{array}$ & $\begin{array}{l}-0.291 \\
(0.301)\end{array}$ & $\begin{array}{l}-0.125 \\
(0.242)\end{array}$ & $\begin{array}{l}-0.300 \\
(0.273)\end{array}$ & $\begin{array}{l}-0.236 \\
(0.200)\end{array}$ \\
\hline Export orientation & $\begin{array}{c}0.623 * * \\
(0.249)\end{array}$ & $\begin{array}{c}0.639 * * \\
(0.261)\end{array}$ & $\begin{array}{c}0.666 * * \\
(0.264)\end{array}$ & $\begin{array}{c}0.342 \\
(0.251)\end{array}$ & $\begin{array}{l}-0.657 * * * \\
(0.250)\end{array}$ & $\begin{array}{l}-0.433 * \\
(0.238)\end{array}$ & $\begin{array}{c}0.614 * * \\
(0.266)\end{array}$ \\
\hline Foreign technology licensing (FTL) & & $\begin{array}{c}0.070 * * \\
(0.032)\end{array}$ & $\begin{array}{c}0.069 * * \\
(0.032)\end{array}$ & $\begin{array}{l}0.068 * \\
(0.077)\end{array}$ & $\begin{array}{l}0.0533 * \\
(0.0289)\end{array}$ & $\begin{array}{l}0.0508 * \\
(0.0283)\end{array}$ & $\begin{array}{c}0.0689 * * * \\
(0.0260)\end{array}$ \\
\hline Collaboration scale (C-scale) & & & $\begin{array}{c}0.142 * * \\
(0.065)\end{array}$ & $\begin{array}{c}0.152 * * \\
(0.067)\end{array}$ & & & $\begin{array}{c}0.151^{*} \\
(0.0912)\end{array}$ \\
\hline FTL*C-scale & & & & $\begin{array}{l}0.873^{*} \\
(0.507)\end{array}$ & & & $\begin{array}{l}0.335^{*} \\
(0.199)\end{array}$ \\
\hline Collaboration scope (C-scope) & & & & & $\begin{array}{l}1.148 * \\
(0.662)\end{array}$ & $\begin{array}{l}1.143 * \\
(0.625)\end{array}$ & $\begin{array}{l}1.888 * \\
(1.027)\end{array}$ \\
\hline FTL $*$ C-scope & & & & & & $\begin{array}{l}0.831 * * * \\
(0.291)\end{array}$ & $\begin{array}{c}0.800 * * * \\
(0.271)\end{array}$ \\
\hline
\end{tabular}




\begin{tabular}{lcccccc}
\hline \hline Deviance & 403.5 & 394.6 & 389.7 & 384.4 & 387.0 & 371.3 \\
LR-test & - & $17.8^{* * *}$ & $27.6^{* * *}$ & $38.2^{* * *}$ & $33^{* * *}$ & $64.4^{* * *}$ \\
df_m & 17 & 18 & 19 & 20 & 19 & 20 \\
\hline
\end{tabular}

a. Standard errors in parentheses

b. $* * * \mathrm{p}<0.01, * * \mathrm{p}<0.05, * \mathrm{p}<0.1$

c. Number of observations $=176$, number of firms $=160$

d. Year and industry dummies were included, but are not shown. 
Figure 1: Licensed foreign technology and local $R \& D$ collaboration in a relational view (adapted from Lavie, 2006)

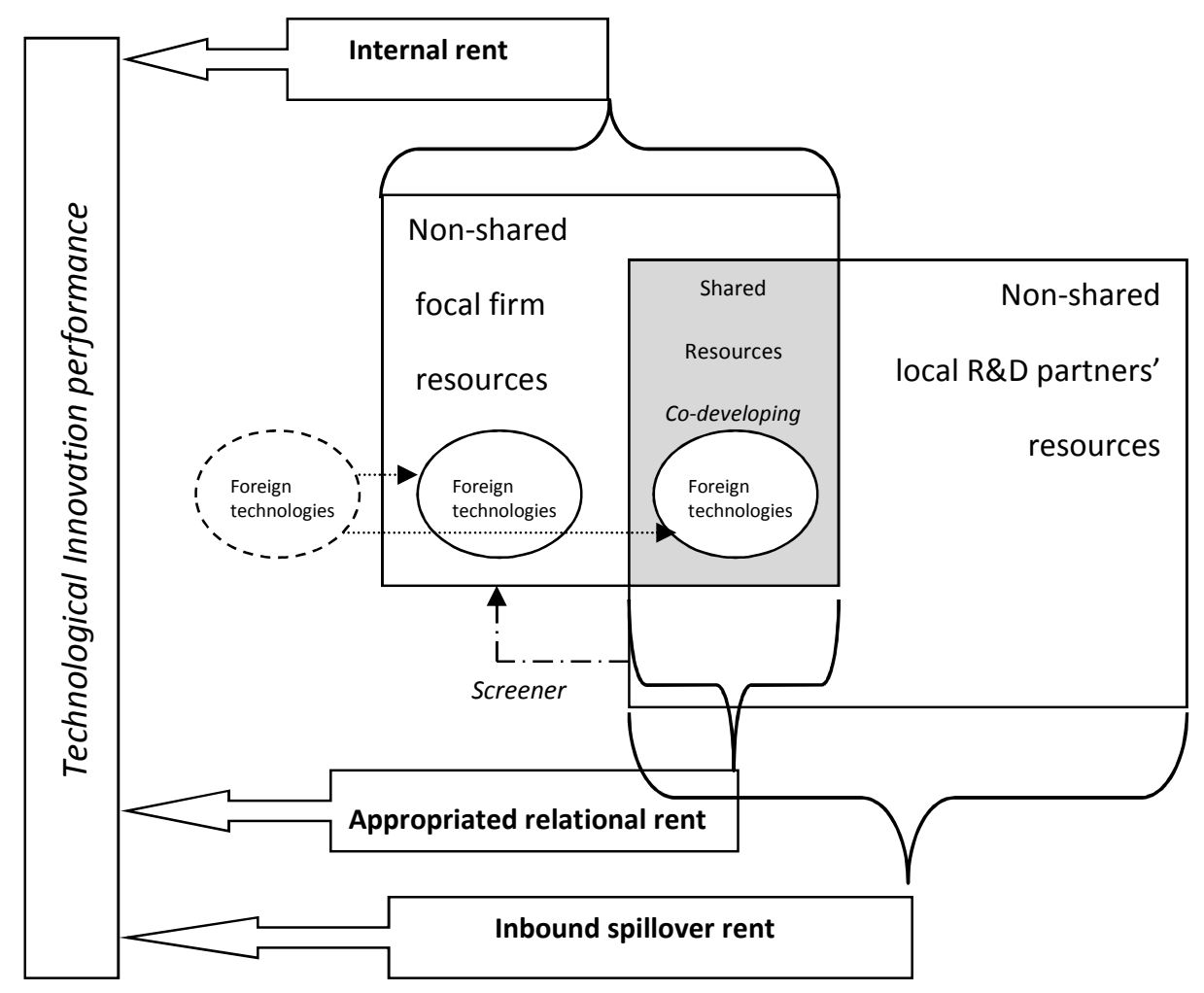

